\title{
FREE VIBRATIONS ANALYSIS OF COMPOSITE LAMINATE PLATES USED IN AUTOMOTIVE INDUSTRY
}

\author{
Aleksandar Radakovićl, Dragan Milosavljević, Gordana Bogdanović, Dragan Čukanović, \\ Vladimir Geroski
}

UDC: $\mathbf{5 3 4 + 5 3 9 . 3 7 ( 6 2 9 . 3 3 )}$

DOI: $10.24874 / \mathrm{mvm} .2017 .43 .04 .04$

\begin{abstract}
The paper describes the process of applying mathematical methods for obtaining analytic solutions in dynamic problems of free vibrations of composite laminate materials which are used in automotive industry. For selected high-order deformation theories the paper presents mathematical method for analytic solving of partial differential equations of motion. The procedure of obtaining results by combining symbolic and numerical values of relevant variables was implemented. Through a kind of comparative analysis, the emphasis was put on the use of HSDTs based on shape functions. Comparative values of results obtained using different shape functions are presented in tabular form. The paper considers simply supported thin, moderately thick and thick laminate plates. Moreover, it shows the influence of the laminate class of symmetry on the method of obtaining results. Simply supported laminate plates were primarily considered, specifically symmetric and anti-symmetric cross-ply laminate plates.
\end{abstract}

KEY WORDS: free vibrations, high-order deformation theories, shape functions, composite materials, analytical solutions

\section{ANALIZA SLOBODNIH VIBRACIJA KOMPOZITNIH LAMINANTNIH PLOČA KORIŠĆENIH U AUTOMOBILSKOJ INDUSTRIJI}

REZIME: Rad opisuje proces primene matematičkih metoda za dobijanje analitičkih rešenja u dinamičkim problemima slobodnih vibracija kompozitnih laminantnih materijala koji se koriste $\mathrm{u}$ automobilskoj industriji. Za izabrane teorije deformacije visokog reda $\mathrm{u}$ radu je predstavljen matematički metod za analitičko rešavanje parcijalnih diferencijalnih jednačina kretanja. Sproveden je postupak dobijanja rezultata kombinovanjem simboličkih i numeričkih vrednosti relevantnih promenljivih. Kroz vrstu komparativnih analiza, naglasak je stavljen na upotrebu HSDT-a baziranih na funkcijama oblika. Komparativne vrednosti rezultata dobijene korišćenjem različitih funkcija oblika prikazane su u tabelarnom obliku. Rad razmatra jednostavno podržane tanke, umereno debele i debele laminantne ploče. Štaviše, pokazuje uticaj laminantne klase simetrije na način dobijanja rezultata. Pre svega se uzimaju u obzir jednostavno podržane laminantne ploče, posebno simetrične i nesimetrične unakrsne laminatne ploče.

${ }^{1}$ Received October 2016, Accepted October 2016, Available on line first December 2017 
KLJUČNE REČI: slobodne vibracije, teorija deformacija visokog reda, funkcije oblika, kompozitni materijali, analitička rešenja 


\title{
FREE VIBRATIONS ANALYSIS OF COMPOSITE LAMINATE PLATES USED IN AUTOMOTIVE INDUSTRY
}

\author{
Aleksandar Radaković ${ }^{1}$, Dragan Milosavljević ${ }^{2}$, Gordana Bogdanović3, \\ Dragan Čukanović ${ }^{4}$, Vladimir Geroski ${ }^{5}$
}

\section{INTRODUCTION}

Continuous development of automotive industry has imposed the need to change conventional materials with new modern ones whenever possible. The basic reason for that lies in the fact that it is necessary to decrease production costs and improve automobile performances on account of decreasing vehicle weight. Decreasing vehicle weight can significantly affect fuel consumption, increase vehicle speed etc. Passengers' safety should also not be forgotten; therefore attention should be paid to the strengths of newly introduced materials. Therefore, it is necessary to do a detailed macro-mechanical and micromechanical analysis of materials which are to be used for.

Alignment angles can also be altered beyond the maker's specifications to obtain a specific handling characteristic. Motorsport and off-road applications may call for angles to be adjusted well beyond "normal" for a variety of reasons.

production. Both in automotive and aircraft industry there is a growing use of composite materials in various forms. The subject of analysis in this paper are multi-layered composite materials, laminates. The key advantage of these materials is their strength in relation to their weight. It is possible to do macro-mechanical analysis of these materials for various types of static and dynamic loadings. Also a big number of theories have been developed for analysis of these problems.

Aiming to eliminate the shortcomings of the Classical Plate Theory (CPT), Mindlin [1] has developed the First-order Shear Deformation Theory (FSDT) taking into consideration shear deformation effects by linear distribution of plane displacements along the thickness of the laminate plate. Since in this case there was also no geometrical nonlinearity for obtaining real solutions, it was necessary to introduce shear correction factors. Shear correction factors are not easy to determine because they depend not only on geometric factors, but also on loadings and boundary conditions. Another theory which takes into consideration shear deformation effects was developed by Reissner [2], [3]. In

\footnotetext{
${ }^{1}$ Aleksandar Radaković, Ph.D.,assist. prof., University of Novi Pazar, Vuka Karađića, bb, 36300 Novi Pazar, Serbia,aradakovic@np.ac.rs

${ }^{2}$ Dragan Milosavljević, Ph.D., prof., University of Kragujevac, Faculty of Engineering in Kragujevac, Sestre Janjić 6, 34000 Kragujevac, dmilos@kg.ac.rs

${ }^{3}$ Gordana Bogdanović, Ph.D., assoc.prof., University of Kragujevac, Faculty of Engineering in Kragujevac, Sestre Janjić 6, 34000 Kragujevac, gocab@kg.ac.rs

${ }^{4}$ Dragan Cukanović, Ph.D, assist.prof., University of Pristina, Faculty of Technical Sciences in Kosovska Mitrovica, Knjaza Miloša 7, 38220 Kosovska Mitrovica,dragan.cukanovic@pr.ac.rs

${ }^{5}$ Vladimir Geroski, Ph.D. student, University of Kragujevac, Faculty of Engineering in Kragujevac, Sestre Janjić 6, 34000 Kragujevac, vlada.geroski@gmail.com
} 
literature the name Mindlin-Reissner theory may often be found, although many authors impugn such a name claiming that the two theories differ considerably [4].

Some authors have tried to solve the problem relating to correction factors by introducing shear deformation shape functions [5-16]. This paper considers the problem of free vibrations of simply supported laminate plates by applying high-order shear deformation theories (HSDT) based on selected shape functions.

\section{THEORETICAL ASSUMPTIONS}

Geometrical non-linearity, in high-order shear deformation theories, is defined by the assumed displacements and there after functions are selected which are to be introduces in to displacements. The aim is to obtain simpler and less mathematically demanding functions, which are the closest to experimental results and the results obtained by the 3D elasticity theory.

The assumed shapes of displacement fields in this case are:

$$
\begin{array}{r}
u(x, y, z, t)=u_{0}=(x, y, t)-z \frac{\partial w}{\partial x}(x, y, t)+f(z) \theta_{x} \\
v(x, y, z, t)=v_{0}=(x, y, t)-z \frac{\partial w}{\partial y}(x, y, t)+f(z) \theta_{y} \\
w(x, y, z, t)=w_{0}=(x, y, t)
\end{array}
$$

where:

$u_{0}, v_{0}, w_{0}$ - displacement of the middle plane of the laminate, $\frac{\partial w}{\partial x}, \frac{\partial w}{\partial y}$ - rotation angles of the normal of plate, $\theta_{x}, \theta_{y}$ - displacement due to transversal shear, $f(z)$ - shape function.

Table 1. Shear deformation shape functions defined by different authors

\begin{tabular}{|c|c|c|}
\hline 1. & Viola et al. [17] & $\frac{2 h}{\pi} \tan \left(\frac{\pi}{2 h} z\right)$ \\
\hline 2. & $\begin{array}{c}\text { Karama et al. [7], } \\
\text { Aydogdu [8] }\end{array}$ & $z e^{-2\left(\frac{z}{h}\right)^{2}},\left[z e^{\frac{-2\left(\frac{z}{h}\right)^{2}}{\ln \alpha}}\right], \forall \alpha>0$ \\
\hline 3. & Mantari et al. [83] & $z \cdot 2.85^{-2\left(\frac{z}{h}\right)^{2}}+0.028 z$ \\
\hline 4. & $\begin{array}{c}\text { El Meiche et al. } \\
{[18]}\end{array}$ & $\xi\left[\frac{h}{\pi} \sin \left(\frac{\pi}{h} z\right)-z\right], \xi=\left\{1,1 / \cosh \left(\frac{\pi}{2} 1-\right\}_{\text {Q }}\right\}$ \\
\hline 5. & Soldatos [6] & $h \sinh (z / h)-z \cosh (1 / 2)$ \\
\hline 6. & $\begin{array}{c}\text { Akavci and } \\
\text { Tanrikulu [19] }\end{array}$ & $z \sec h\left(\frac{z^{2}}{h^{2}}\right)-z \operatorname{sech}\left(\frac{\pi}{4}\right)\left[1-\frac{\pi}{2} \tanh \left(\frac{\pi}{4}\right)\right]$ \\
\hline
\end{tabular}




\begin{tabular}{|c|c|c|}
\hline 7. & Grover et al. [21] & $z \sec \left(\frac{r z}{h}\right)-z \sec \left(\frac{1}{2}\right) /\left(1+\frac{r}{2} \tan \left(\frac{r}{2}\right)\right), r=0.1$ \\
\hline 8. & Mechab et al. [20] & $\frac{z \cos \left(\frac{1}{2}\right)}{-1+\cos \left(\frac{1}{2}\right)}-\frac{h \sin \left(\frac{z}{h}\right)}{-1+\cos \left(\frac{1}{2}\right)}$ \\
\hline
\end{tabular}

In order to define components of unit loads, it is necessary to apply the relations between displacements and strains in accordance with the well known theory of linear elasticity. Using a generalized Hooke's law the following components of unit loads are obtained:

$$
\begin{gathered}
\mathbf{N}=\int_{h^{-}}^{h^{+}} \boldsymbol{\sigma} d z=\sum_{l=1}^{n}\left(\int_{h_{l}^{-}}^{h_{1}^{+}} \mathbf{Q}^{y} \mathbf{k}_{0} d z+\int_{h_{l}^{-}}^{h_{l}^{+}} \mathbf{Q}^{\prime} \mathbf{k}_{1} z d z+\int_{h_{l}^{-}}^{h_{1}^{+}} \mathbf{Q}^{\prime} \mathbf{k}_{2} f(z) d z\right) \\
\mathbf{M}=\int_{h^{-}}^{h^{+}} \boldsymbol{\sigma} z d z=\sum_{l=1}^{n}\left(\int_{h_{l}^{-}}^{h_{l}^{+}} \mathbf{Q}^{y} \mathbf{k}_{0} z d z+\int_{h_{l}^{-}}^{h_{l}^{+}}\left(\mathbf{Q}^{\prime} \mathbf{k}_{1} z d z+\int_{h_{l}^{-}}^{h_{l}^{+}} \mathbf{Q}^{\prime} \mathbf{k}_{2} z f(z) d z\right),\right. \\
\mathbf{P}=\int_{h^{-}}^{h^{+}} \boldsymbol{\sigma} f(z) d z=\sum_{l=1}^{n}\left(\int_{h_{l}^{-}}^{h_{1}^{+}} \mathbf{Q}^{(/)} \mathbf{k}_{0} f(z) d z+\int_{h_{l}^{-}}^{h_{l}^{+}} \mathbf{Q}^{(/)} \mathbf{k}_{1} z f(z) d z+\int_{h_{l}^{-}}^{h_{1}^{+}} \mathbf{Q}^{(/)} \mathbf{k}_{2}(f(z))^{2} d z\right), \\
\mathbf{R}=\int_{h^{-}}^{h^{+}} \mathbf{T} f^{\prime}(z) d z=\sum_{l=1}^{n} \int_{h_{l}^{-}}^{h_{1}^{+}} \mathbf{Q}_{\mathrm{s}}^{y} \mathbf{k}_{\mathbf{s}}(f(z))^{2} d z,
\end{gathered}
$$

where:

$$
\begin{aligned}
& \mathbf{Q}=\left[\begin{array}{lll}
\mathbf{Q}_{11} & \mathrm{Q}_{12} & \mathrm{Q}_{16} \\
\mathbf{Q}_{12} & \mathrm{Q}_{22} & \mathrm{Q}_{26} \\
\mathbf{Q}_{16} & \mathrm{Q}_{26} & \overline{\mathrm{C}}_{66}
\end{array}\right], \mathbf{Q}_{\mathcal{S}}=\left[\begin{array}{ll}
\mathbf{Q}_{44} & \mathbf{Q}_{45} \\
\mathbf{Q}_{45} & \mathbf{Q}_{55}
\end{array}\right], \boldsymbol{\sigma}=\left\{\begin{array}{lll}
\sigma_{x x} & \sigma_{y y} & \sigma_{x y}
\end{array}\right\}^{T}, \mathbf{T}=\left\{\begin{array}{ll}
\tau_{x z} & \tau_{y z}
\end{array}\right\}^{T}, \\
& \mathrm{~N}=\left\{\begin{array}{lll}
N_{x x} & N_{y y} & N_{x y}
\end{array}\right\}^{T}, \mathrm{M}=\left\{\begin{array}{lll}
M_{x x} & M_{y y} & M_{x y}
\end{array}\right\}^{T}, \mathrm{P}=\left\{\begin{array}{lll}
P_{x x} & P_{y y} & P_{x y}
\end{array}\right\}^{T} \text {, }
\end{aligned}
$$

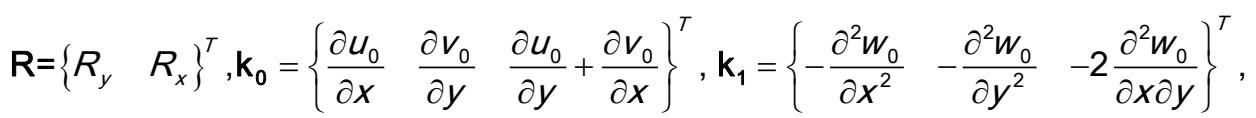

$$
\begin{aligned}
& \mathbf{k}_{\mathbf{2}}=\left\{\begin{array}{lll}
\frac{\partial \theta_{x}}{\partial x} & \frac{\partial \theta_{y}}{\partial y} & \frac{\partial \theta_{x}}{\partial y}+\frac{\partial \theta_{y}}{\partial x}
\end{array}\right\}^{T}, \mathbf{k}_{\mathbf{s}}=\left\{\begin{array}{ll}
\theta_{x} & \theta_{y}
\end{array}\right\}^{T} \text {. }
\end{aligned}
$$

In the eq. (3), by grouping the terms with the elements of constitutive matrix, it is possible to define new matrices: 


$$
\begin{aligned}
& \left(A_{i j}, B_{i j}, \mathrm{D}_{i j}, \mathrm{E}_{i j}, F_{i j}, G_{i j}\right)=\sum_{l=1}^{n} \int_{h_{l}^{-}}^{h_{1}^{+}} Q_{i j}^{(l)}\left(1, z, f(z), z^{2}, z f(z),(f(z))^{2}\right) d z, i, j=(1,2,6), \\
& H_{i j}=\sum_{l=1}^{n} \int_{h^{-}}^{h^{+}} Q_{i j}^{(l)}\left(f^{\prime}(z)\right)^{2} d z,(i, j)=(4,5) .
\end{aligned}
$$

Using the Hamilton principles, equilibrium equations become:

$$
\begin{aligned}
& \delta u_{0}: N_{x x, x}+N_{x y, y}=I_{1} \ddot{u}-I_{2} \ddot{w}_{, x}+I_{4} \ddot{\theta}_{x}, \delta v_{0}: N_{y y, y}+N_{x y, x}=I_{1} \ddot{v}-I_{2} \ddot{w}_{, y}+I_{4} \ddot{\theta}_{y}, \\
& \delta w_{0}: M_{x x, x x}+2 M_{x y, x y}+M_{y y, y y}=I_{1} \ddot{w}+I_{2}\left(\ddot{u}_{, x}+\ddot{v}_{, y}\right)-I_{3}\left(\ddot{w}_{, x x}+\ddot{w}_{, x x}\right)+I_{5}\left(\ddot{\theta}_{x x}+\ddot{\theta}_{y x}\right), \\
& \delta \theta_{x}: P_{x x, x}+P_{x y, y}-R_{x}=I_{4} \ddot{u}-I_{5} \ddot{w}_{, x}+I_{6} \ddot{\theta}_{x}, \delta \theta_{y}: P_{x y, x}+P_{y y, y}-R_{y}=I_{4} \ddot{v}-I_{5} \ddot{w}_{, y}+I_{6} \ddot{\theta}_{y} .
\end{aligned}
$$

where:

$$
I_{1 \ldots 6}=\sum_{l=1}^{n} \int_{h_{l}^{-}}^{h_{1}^{+}} \rho_{l}\left(1, z, f(z), z^{2}, z f(z),(f(z))^{2}\right) d z
$$

\section{NUMERICAL RESULTS}

The aim of this chapter is to check the correctness and efficiency of the presented theory for determining dimensionless frequency of simply supported cross-ply laminate plates. In order to do that, different numerical examples were done, and the obtained results were compared with the results available in the literature.

Analytical procedure requires defining of boundary conditions and assuming the solutions of dynamic equations of motion. Boundary conditions are defined as [22]:

$$
\begin{aligned}
& v_{0}=w_{0}=\theta_{y}=N_{x}=M_{x}=P_{x}=0, \text { at the edges } x=0, x=a, \\
& u_{0}=w_{0}=\theta_{x}=N_{y}=M_{y}=P_{b}=0, \text { at the edges } \mathrm{y}=0, y=b .
\end{aligned}
$$

Taking into consideration previously defined boundary conditions based on [19] it is possible to assume Navier solution to have the form: 


$$
\begin{aligned}
& u_{0}(x, y, t)=\sum_{m=1}^{\infty} \sum_{n=1}^{\infty} U_{m n} \cos \frac{m \pi x}{a} \sin \frac{n \pi y}{b} e^{i \omega t}, \\
& v_{0}(x, y, t)=\sum_{m=1}^{\infty} \sum_{n=1}^{\infty} V_{m n} \sin \frac{m \pi x}{a} \cos \frac{n \pi y}{b} e^{i \omega t}, \\
& w_{0}(x, y, t)=\sum_{m=1}^{\infty} \sum_{n=1}^{\infty} W_{m n} \sin \frac{m \pi x}{a} \sin \frac{n \pi y}{b} e^{i \omega t}, \\
& \theta_{x}(x, y, t)=\sum_{m=1}^{\infty} \sum_{n=1}^{\infty} T_{x m n} \cos \frac{m \pi x}{a} \sin \frac{n \pi y}{b} e^{i \omega t}, \\
& \theta_{y}(x, y, t)=\sum_{m=1}^{\infty} \sum_{n=1}^{\infty} T_{y m n} \sin \frac{m \pi x}{a} \cos \frac{n \pi y}{b} e^{i \omega t} .
\end{aligned}
$$

where are arbitrary parameters which should be determined.

For thus defined boundary conditions and assumed form of analytic solutions, equations of dynamic equilibrium are reformed into:

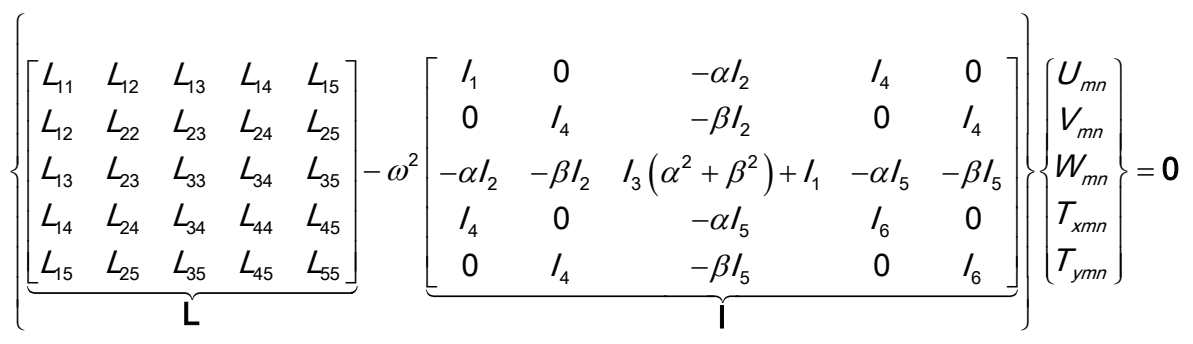

where , and coefficients obtained by analytical procedure. For obtaining nontrivial solutions of the equation (8) it is necessary that the determinant of the first matrix in the product is equal to zero, that is:

$$
\left|L-\omega^{2}\right| \mid=0
$$

For presenting the obtained numerical values it is necessary to normalize the obtained values in accordance with [18] as $\bar{\omega}=\frac{a b}{h} \sqrt{\frac{\rho}{E_{2}}}$. Thus a dimensionless value of the frequency is obtained, which for $m=1 i n=1$, relates to the first oscillation mode. The results were obtained in the software Matlab by combining symbolic and numerical values of variables.

Material properties used in the numerical examples were the following [21]:

$$
E_{1} / E_{2}=\text { open, } \mathrm{G}_{12} / E_{2}=0.6, \mathrm{G}_{13} / E_{2}=0.6, \mathrm{G}_{23} / E_{2}=0.5, v_{12}=v_{13}=v_{23}=0.25
$$

Calculated values of the dimensionless frequency are given in the Tables 2 and 3 . Table 2 presents dimensinoless values of the first oscillation mode of the laminate plate, for different values of the relation, at a fixed relation. It can be seen that for all proposed shape functions it is possible to obtain solution for dimensionless frequency. The differences in results obtained by various shape functions grow with the increase of the relation, which can most clearly be seen in the shape function proposed by Viola at al. Generally, the method which was implemented in Matlab provides good matching with the values presented in the papers of authors dealing with these problems [9], [22], [23], [24]. 
Table 2. Values of dimensionless frequency $\bar{\omega}$ of symmetric cross-ply laminate $\left[0^{\circ} / 90^{\circ} / 90^{\circ} / 0^{\circ}\right]$ at a changing relation $E_{1} / E_{2}$, and the fixed relation $\frac{a}{h}=5$

\begin{tabular}{|c|c|c|c|c|c|}
\hline \multirow{2}{*}{$\begin{array}{c}\text { Name of the } \\
\text { author }\end{array}$} & \multicolumn{5}{|c|}{$E_{1} / E_{2} \quad m=1, n=1$} \\
\cline { 2 - 6 } & 3 & 5 & 10 & 20 & 50 \\
\hline Viola et al. & 6.793 & 7.509 & 8.816 & 10.420 & 12.709 \\
\hline $\begin{array}{c}\text { Karama et al., } \\
\text { Aydogdu }\end{array}$ & 6.592 & 7.245 & 8.399 & 9.743 & 11.494 \\
\hline Mantari et al. & 6.592 & 7.246 & 8.400 & 9.746 & 11.494 \\
\hline El Meiche et al. & 6.592 & 7.246 & 8.400 & 9.746 & 11.449 \\
\hline Soldatos & 6.585 & 7.233 & 8.374 & 9.698 & 11.419 \\
\hline $\begin{array}{c}\text { Akavci and } \\
\text { Tanrikulu }\end{array}$ & 6.587 & 7.232 & 8.367 & 9.683 & 11.409 \\
\hline Grover et al. & 6.673 & 7.344 & 8.540 & 9.957 & 11.876 \\
\hline Mechab et al. & 6.585 & 7.233 & 8.375 & 9.700 & 11.423 \\
\hline
\end{tabular}

Table 3. Values of dimensionless frequency $\bar{\omega}$ of symmetric laminate $\left[0^{\circ} / 90^{\circ} / 90^{\circ} / 0^{\circ}\right]$ at a changing relation $a / h$, the fixed relation $\mathrm{E}_{1} / \mathrm{E}_{2}=40$

\begin{tabular}{|c|c|c|c|c|c|}
\hline \multirow{2}{*}{$\begin{array}{c}\text { Name of the } \\
\text { author }\end{array}$} & \multicolumn{5}{|c|}{$\mathrm{a} / \mathrm{h} m=1, n=1$} \\
\cline { 2 - 6 } & 2 & 4 & 10 & 50 & 100 \\
\hline Viola et al. & 6.67 & 10.711 & 16.030 & 18.740 & 18.853 \\
\hline $\begin{array}{c}\text { Karama et al. } \\
\text { Aydogdu }\end{array}$ & 5.659 & 9.581 & 15.383 & 18.695 & 18.842 \\
\hline $\begin{array}{c}\text { Mantari et al. } \\
\text { El Meiche et } \\
\text { al. }\end{array}$ & 5.664 & 9.585 & 15.386 & 18.696 & 18.842 \\
\hline Soldatos & 5.586 & 9.520 & 15.327 & 18.691 & 18.842 \\
\hline Akavci et al. & 5.578 & 9.517 & 15.299 & 18.688 & 18.840 \\
\hline Grover et al. & 5.908 & 9.94 & 15.570 & 18.708 & 18.854 \\
\hline Mechab et al. & 5.590 & 9.524 & 15.330 & 18.691 & 18.8414 \\
\hline
\end{tabular}

Table 2 presents the values of dimensionless frequency $\bar{\omega}$ of symmetric cross-ply laminate plates $\left[0^{\circ} / 90^{\circ} / 90^{\circ} / 0^{\circ}\right]$ at a changing relation a $/ \mathrm{h}$ and the fixed relation $E_{1} / E_{2}$. With thick and moderately thick plates, where a / h $<20$ there are bigger discrepancies in the values of the dimensionless frequency. Great deviations have been noticed at functions defined by Viola et al., Grover et al. so that it can be said that these functions are not 
applicable to this type of problems. With thin plates where a / $\mathrm{h} \geq 20$ it can be seen that all theories give results which match in two decimals, which is in accordance to the fact that the influence of HSDT decreases with the increase of the relation a / h. During the process it has been noted that only in the cases of functions which are marked in the Tables 2 and 3, it is not necessary to use numerical integration, so that the accuracy of obtained results is the biggest. All other functions require the use of numerical integration, and they are, therefore, developed primarily for numerical methods like finite elements method or finite differences method.

Diagrams in the Figure 1 show pretty good matching of results obtained using almost all shape functions. Somewhat bigger deviations have been noticed at shape functions defined by Viola et al. Figure 1a presents the values of dimensionless frequency in the function of the change of the relation a / $\mathrm{h}$ at the fixed values of the relation $E_{1} / E_{2}$. With thick and moderately thick plates, up to the relation a / $\mathrm{h}<20$ the value of dimensionless frequency is growing. Above the mentioned limit for all shape functions, the values start to become asymptotic closer to some fixed value. When it comes to thin plates, the influence of shape function decreases, so that it can be concluded that using shape functions at thin plates is not crucial and satisfactory results could be obtained using theories of lower order.

Diagrams in the Figure 1 show pretty good matching of results obtained using almost all shape functions. Somewhat bigger deviations have been noticed at shape functions defined by Viola et al. Figure 1a presents the values of dimensionless frequency in the function of the change of the relation a / h at the fixed values of the relation $E_{1} / E_{2}$. With thick and moderately thick plates, up to the relation a $/ \mathrm{h}<20$ the value of dimensionless frequency is growing. Above the mentioned limit for all shape functions, the values start to become asymptotic closer to some fixed value. When it comes to thin plates, the influence of shape function decreases, so that it can be concluded that using shape functions at thin plates is not crucial and satisfactory results could be obtained using theories of lower order.

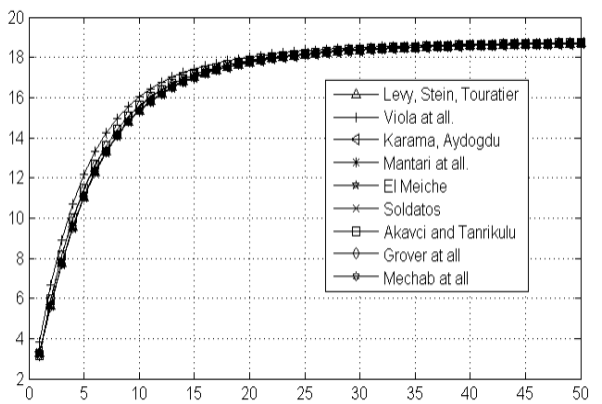

$\mathrm{a} / \mathrm{h}$

a) $E_{1} / E_{2}=40$

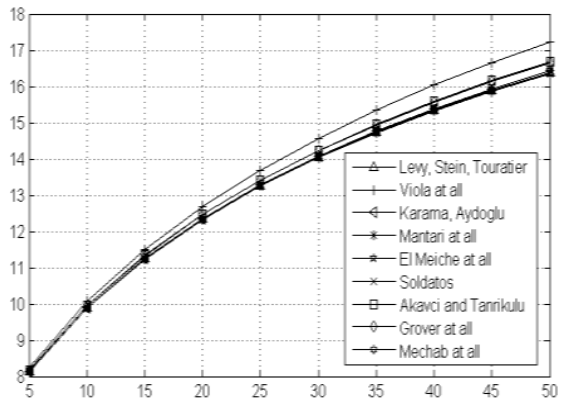

$\mathrm{E}_{1} / \mathrm{E}_{2}$

б) $a / h=10$

Figure 1. Values of dimensionless frequency $\bar{\omega}$ in the function of the change of relations

$$
\text { a) } E_{1} / E_{2}=40 \text { b) } a / h=10
$$

Figure $1 \mathrm{~b}$ shows, through a diagram, functional dependence of dimensionless frequency at fixed value of the relation $\mathrm{a} / \mathrm{h}=10$ and a changing relation of the elasticity module $E_{1} / E_{2}$. Unlike the previous case, here there is no asymptotic approaching to some finite value. It can also be clearly seen that all shape functions, apart from the functions 
defined by Viola, Akavci and Tanrikulu, give curves which make one family of curves. With the growth of the relation of elasticity module, the mentioned two functions begin to increasingly diverge from the defined families of curves

\section{CONCLUSIONS}

Laminate materials, as materials of contemporary engineering structures have growing use in automotive industry. Accordingly, the paper presents the dynamic analysis of the problem of own vibrations of these materials from the aspect of the use of some proposed shape functions. The results obtained by applying the developed and implemented 2D high-order shear deformation theories give satisfactory accuracy, and the very method is much simpler than 3D elasticity theory. Thus the efficiency of macro-mechanical analysis is increased. It has been shown that all proposed shape functions are not applicable to the problem of free vibrations. It has also demonstrated that the use of these functions is important only for thick and moderately thick plates. Generally, the idea was to select the most simple shape function which would give satisfactory results. Comparative analysis has shown that for problems of own vibrations shape functions which are analytically integrable can be used. In that sense, the use of analytically integrable functions proved to require shorter calculation time. Shape functions which need numerical integration have not proved to be dominant over analytically integrable functions. With these functions for obtaining results it was necessary to go to some of the numerical integration methods. From this aspect, the best results with the shortest calculation time have been obtained using shape functions defined by Soldatos and Mechab. These two functions gave solutions of integrals in the closed form, and the procedure is therefore much faster and simpler. Commercial software for structure analysis using finite elements are mainly based on Mindlin's theory which requires correction factors which depend on geometry and shape. It has been shown here that it is possible to apply analytically integrable shape functions for free vibrations problems of simply supported laminate plates. The confirmation of this claim is to be found by creation of material model of laminate plates based on shape functions.

\section{ACKNOWLEDGMENT}

This investigation is a part of the projects TR 33015, TR 32036 and multidisciplinary project III 44007 of Technological Development of the Republic of Serbia. We would like to thank to the Ministry of Education and Science of Republic of Serbia for the financial support during this investigation.

\section{REFERENCES}

[1] Mindlin R.D., Influence of rotatory inertia and shear on flexural motions of isotropic, elastic plates, J Appl Mech,; 18(1):31-8, 1951.

[2] Reissner E., On bending of elastic plates, Q Appl Math,; 5(1):55-68, 1947.

[3] Reissner E., The effect of transverse shear deformation on the bending of elastic plates, J Appl Mech,; 12(2):69-72, 1945.

[4] Wang C.M., Lim G.T., Reddy J.N., Lee K.H., Relationships between bending solutions of Reissner and Mindlin plate theories, Eng Struct; 23(7):838-49, 2001. 
[5] Touratier M., An efficient standard plate theory, Int J Eng Sci; 29(8):901-16, 1991.

[6] Soldatos K., A transverse shear deformation theory for homogeneous monoclinic plates, Acta Mech; 94(3):195-220, 1992.

[7] Karama M., Afaq K.S., Mistou S., Mechanical behaviour of laminated composite beam by the new multi-layered laminated composite structures model with transverse shear stress continuity, Int J Solids Struct; 40(6):1525-46, 2003.

[8] Aydogdu M., A new shear deformation theory for laminated composite plates, Compos Struct; 89(1):94-101, 2009.

[9] Mantari J.L., Oktem A.S., Guedes Soares C., A new trigonometric shear deformation theory for isotropic, laminated composite and sandwich plates, Int J Solids Struct; 49(1):43-53, 2012.

[10] Mantari J.L., Guedes Soares C., Bending analysis of thick exponentially graded plates using a new trigonometric higher order shear deformation theory, Compos Struct, 2012; 94(6):1991-2000.

[11] Mantari J.L., Oktem A.S., Guedes Soares C., A new higher order shear deformation theory for sandwich and composite laminated plates, Compos B Eng; 43(3):1489-99, 2012.

[12] Mantari J.L., Oktem A.S., Guedes Soares C., Bending response of functionally graded plates by using a new higher order shear deformation theory, Compos Struct; 94(2):714-23, 2012.

[13] Mantari J.L., Oktem A.S., Guedes Soares C., Bending and free vibration analysis of isotropic and multilayered plates and shells by using a new accurate higherorder shear deformation theory, Compos B Eng; 43(8):3348-60, 2012.

[14] Mantari J.L., Guedes Soares C., Analysis of isotropic and multilayered plates and shells by using a generalized higher-order shear deformation theory, Compos Struct; 94(8):2640-56, 2012.

[15] Mantari J.L., Guedes Soares C., Finite element formulation of a generalized higher order shear deformation theory for advanced composite plates, Compos Struct; 96:545-53, 2013.

[16] Mantari J.L., Bonilla E.M., Guedes Soares C., A new tangential-exponential higher order shear deformation theory for advanced composite plates, Compos B Eng; 60:319-28, 2014.

[17] Viola E., Tornabene F., Fantuzzi N., General higher-order shear deformation theories for the free vibration analysis of completely doubly-curved laminated shells and panels, Composite structures; 95:639-666, 2013.

[18] Meiche N. E. et al. A new hyperbolic shear deformation theory for buckling and vibration of functionally graded sandwich plate, International Journal of Mechanical Sciences; 53:237-247, 2011.

[19] Akavci S.S., Two new hyperbolic shear displacement models for orthotropic laminated composite plates, Mech Compos Mater; 46(2):215-26, 2010.

[20] Mechab Belaid, Mechab Ismail, Benaissa Samir, Analysis of thick orthotropic laminated composite plates based on higher order shear deformation theory by the new function under thermo-mechanical loading, Composites: Part B; 43:1453-8, 2012.

[21] Grover N., Maiti D.K., Singh B.N., Flexural behavior of general laminated composite and sandwich plates using a secant function based shear deformation theory, Latin American Journal of Solids and Structures; 11:1275-1297, 2014.

[22] Reddy J.N., Mechanics of Laminated Composite Plates and Shells: Theory and Analysis, CRC Press LLC, London and New York; ISBN 0-8493-1592-1, 2004. 
[23] Kant T., Swaminathan K., Analytical solutions for the static analysis of laminated composite and sandwich plates based on a higher order refined theory, Compos Struct; 56:329-44, 2002.

[24] Sahoo R., Singh B.N., A new trigonometric zigzag theory for buckling and free vibration analysis pf laminated composite and sandwich plates, Composite structures; 117:316-332, 2014. 